\section{La representación visual del movimiento estudiantil chileno en la prensa establecida y alternativa nacional: Un análisis multimodal}

The visual representation of the Chilean students' movement in the national established and alternative press: A multimodal analysis

\section{Carolina Pérez-Arredondo*}

\section{Resumen}

Este artículo analiza la construcción visual del movimiento estudiantil en la prensa tradicional y digital del 4 de agosto de 2011. Se considera esta protesta en particular puesto que se efectúo una represión particularmente notoria (Vera 2012). El corpus de estudio corresponde a imágenes extraídas de artículos que cubrieron

Doctoranda en Lingüística. Departamento de Lingüística y Lengua Inglesa, Universidad de Lancaster, Lancaster, LA1 4YL, Inglaterra. Correo electrónico: cperez.arredondo@gmail.com. esta manifestación, las cuales fueron analizadas bajo el marco propuesto por Kress y van Leeuwen (2006), complementado con el enfoque de Actores Sociales de van Leeuwen (2008) y un breve análisis auxiliar del corpus textual (Baker 2006; Baker et al. 2011). Los resultados evidencian cómo opera la deslegitimación entre texto e imágenes: la agentividad reflejada en las imágenes intensifica las estrategias lingüísticas de deslegitimación tales como criminalización, colectivización y exclusión. En este sentido, las estrategias utilizadas por los medios de comunicación refuerzan narrativas basadas en el conflicto y perpetúan la exclusión del discurso de los movimientos sociales en la prensa tradicional.

Palabras clave: Análisis multimodal, movimiento estudiantil Chile, prensa chilena, Análisis Crítico del Discurso (ACD)

\section{Abstract}

This paper examines how the Chilean students' movement was visually constructed in traditional and alternative media during one of the most violent and repressive demonstrations in August, 2011 (Vera 2012). My corpus is comprised by images taken from articles which covered this demonstration, which are analysed in light of Kress and van Leeuwen's (2006) visual grammar, complemented with van Leeuwen's (2008) Social Actor Approach. Likewise, I complemented this analysis by applying a corpus-assisted approach (Baker 2006; Baker et al. 2011) to the articles from the textual corpus. Results unveil how images and text work together to delegitimize specific social actors: the agency represented in these 
images intensifies linguistic strategies such as criminalization, collectivisation, and exclusion. The strategies used by established media reinforce a narrative construction based on the criminalization of social actors challenging the status quo, perpetuating the exclusion of the discourse proposed by social movements in the established media.

Key words: Multimodal analysis, Chilean students' movement, Chilean press, Critical Discourse Analysis (CDA)

\section{Introducción}

A pesar del gran apoyo ciudadano generado por el movimiento estudiantil chileno durante el 2011, demostrado a través de numerosas manifestaciones, los medios de comunicación nacionales mostraron una clara tendencia a reportar las acciones estudiantiles desde un lente institucional, predominando una criminalización sistemática de los estudiantes y actores sociales involucrados (Pérez 2012). Si bien esta tendencia a la criminalización se correlaciona con diversas investigaciones llevadas a cabo en el marco de la sociología y estudios de medios de comunicación (Chan y Lee 1984; Shoemaker 1984; McLeod 2007, entre otros), son muy pocos aquellos que ahondan en el asunto desde un enfoque lingüístico (Colorado 2011).

Es por ello que este artículo pretende examinar la construcción multimodal del movimiento estudiantil chileno en la prensa escrita de alcance nacional, bajo el marco de un Análisis Crítico del Discurso (ACD), utilizando la gramática visual propuesta por Kress y van Leeuwen (2006) y el Enfoque de Actores Sociales de van Leeuwen (2008). En particular, se busca identificar la función que cumplen las imágenes en la representación de jóvenes estudiantes involucrados en movimientos sociales en una protesta crucial para el movimiento, como lo fue aquella del 4 de agosto de 2011 (Vera 2012; Zúñiga 2012). Se incluye, además, un breve análisis textual (asistido con métodos de análisis de corpus (Baker 2006; Baker et al. 2011) de los artículos que contienen las imágenes de carácter auxiliar, debido a que fue una forma de corroborar los resultados del análisis visual.

Este estudio se estructura de la siguiente manera: primero, se entregan las bases teóricas sobre las que se fundamenta la investigación, explicando brevemente el rol de las imágenes en los medios de comunicación y el estado actual de la prensa nacional, enfatizando las ventajas de realizar un análisis crítico discursivo al estudio de movimientos sociales; segundo, se describe el corpus de estudio y las metodologías a utilizar durante el análisis; $\mathrm{y}$, finalmente, se presentan los resultados y las interpretaciones que derivan de estos, seguidos de las conclusiones del estudio.

\section{Marco teórico y contextual}

De acuerdo a diversos estudios en el área, la multimodalidad se refiere a recursos semióticos que utilizamos al momento de comunicarnos (signos, sonidos, etc.) y que están determinados socialmente, posibilitando infinitas construcciones de realidades, significados y mediaciones que dejan entrever nuestras ideologías y motivaciones (ver, por ejemplo, van Leeuwen y Jewitt 2001; Machin 2007, 2013; Kress 2010; O'Halloran 2011). Al considerar la influencia que los medios de comunicación 
tienen al moldear y crear realidades a través del lenguaje (Mautner 2008), y la (a veces desatendida) importancia de las imágenes incluidas en los reportes noticiosos, el análisis de todos los recursos semióticos presentes en los reportes sobre el movimiento estudiantil en la prensa escrita resulta no solo pertinente, sino que indispensable.

\subsection{La fotografía periodística}

Durante mucho tiempo, las imágenes en la prensa fueron consideradas como dependientes de las descripciones verbales de las noticias (Zelizer 2004), resaltándose su capacidad de ser un "medio técnico para representar la realidad" (Dondis 1973: 69-70). Si bien esta aparente objetividad ha sido ampliamente abordada (ver el trabajo de Barthes 1977, por ejemplo), la fotografía sí se interpreta como un medio que posee el efecto de representar una "impresión de verdad" (Torres 2006), dependiente del contexto en el que se le presenta, de las subjetividades del fotógrafo, etc. Muchas veces, en pos de esa impresión de realidad, el fotógrafo busca la imagen que cause una mayor atención y/o efecto, transformándose en un ícono visual social (por ejemplo, la fotografía de "La niña del Napalm" tomada por Nick Ut durante los bombardeos en Vietnam dio la vuelta al mundo). El efecto "visceral" con el cual recibimos las fotografías es un factor que también tiene un efecto sobre la forma en la que interpretamos las imágenes, ya que las "reacciones emocionales por parte del lector en relación al contenido de la imagen obscurecen la forma de la imagen: los procesos utilizados para construir la imagen" (Caple 2013: 4).

Es solo durante las últimas décadas que la fotografía de prensa ha cobrado relevancia alejándose de la idea de ser solo un elemento complementario al texto. Esta reivindicación de la importancia de la fotografía se debe, entre otros factores, a los avances realizados en el área de la semiótica social de las imágenes (ver sección 2.2) en los medios de comunicación (Caple 2013). Así, se comienza a abordar el carácter polisémico de la fotografía y su rol dentro de la contextualización del discurso noticioso, además de los efectos que estas implican en los contextos comunicativos e históricos donde se encuentran inmersas.

\subsection{La gramática de lo visual}

El trabajo de Kress y van Leuuwen nace como una contribución no solo teórica, sino también práctica para comprender los distintos modos (modes) con los cuales construimos significados al hablar. En palabras de estos autores: "vemos las imágenes de cualquier tipo como pertenecientes en su totalidad al ámbito de las realizaciones y representaciones (instantiations) de ideologías, -siempre- como medios para la articulación de posiciones (ejercicios) ideológicos" (2006: 14). Se entiende, por lo tanto, la importancia que las ciencias y disciplinas críticas le atribuyen al análisis visual, especialmente en el área de la lingüística, donde se ha puesto un claro énfasis en el análisis de textos (lingüísticos) para desvelar relaciones (desiguales) de poder.

Para Kress y van Leeuwen, el análisis de imágenes se puede abordar considerando tres funciones básicas, utilizando conceptos extraídos de la gramática sistémico-funcional de Halliday (2004). Así, los significados de las imágenes pueden ser representacionales, composicionales e interpersonales (Kress y van Leeuwen 2006). 
El significado representacional consiste en la representación de participantes y acciones, y de cómo estos se relacionan entre sí. De este significado se distinguen dos tipos de representaciones: narrativas y conceptuales. Las primeras se centran en la representación de las acciones, eventos y procesos, que pueden ser entendidos y analizados a través de vectores que simbolizan la direccionalidad y el tipo de interacción revelados en la imagen (por ejemplo, pueden existir imágenes donde un actor dirija la acción a un objetivo -interacción transitiva- o no -interacción intransitiva-; en otras se representará solo el vector y el objetivo de la acción -un evento-). Por otro lado, las representaciones conceptuales se centran en la representación de los participantes tal y como son, donde rasgos tales como la edad, clase social, raza, entre otros, cobran relevancia.

El significado composicional incluye distintos factores que contribuyen a la organización de los actores y eventos representados en una imagen, tales como su valor informativo, su prominencia y encuadre (framing). Su valor informativo se basa en los significados socialmente determinados para las distintas zonas de la imagen. Bajo este parámetro, y considerando las variables culturales de la cultura occidental, se entiende que la dicotomía izquierda/derecha representa lo conocido y lo nuevo, respectivamente, mientras que la dicotomía arriba/abajo representa las dimensiones de lo ideal y lo real. En este sentido, lo central/marginal también proporciona interpretaciones determinadas pertinentes a lo que es considerado como central o periférico culturalmente. Por último, mientras la prominencia de la imagen se refiere a la importancia que se le da a ciertos actores o eventos a través del uso de características específicas en la imagen (tamaño, uso de primer y segundo plano, contrastes, texturas, iluminación, etc.), el encuadre contribuye a cómo se entienden los elementos de una imagen en términos de pertenencia o unidad (Kress y van Leeuwen 2006).

Finalmente, el significado interpersonal se refiere a la interacción entre los participantes y eventos representados y el observador de la imagen. Los elementos a considerar en la construcción de este significado son el contacto simbólico, la distancia social y la actitud. Si bien el contacto simbólico se refiere, básicamente, al rol del observador en la imagen (pudiendo ser objetivo de los actores representados o demand o relegado al rol de observador pasivo u offer), la distancia social se refiere a qué tan cercanos o lejanos son construidos los actores de la imagen en relación al observador. Kress y van Leeuwen (2006) distinguen tres tipos de distancia: íntima (actor y observador se posicionan dentro del espacio personal del otro), social (reflejada en una toma mediana, donde el actor es representado desde las rodillas hacia arriba), e impersonal (distancia que facilita que el actor y el observador se consideren extraños). Por último, la actitud tiene que ver con las distintas evocaciones de objetividad o subjetividad en donde se expresan las relaciones de poder entre actor y observador (un ángulo alto refleja a un observador empoderado, mientras que uno bajo representa lo opuesto; un ángulo a nivel de la mirada refleja igualdad en la relación).

Es importante señalar la necesidad de considerar el contexto cultural, social y político nacional de las imágenes al momento de realizar un análisis e interpretar resultados. El enfoque semiótico social, al igual que la propuesta de Kress y van Leeuwen, se basa en la premisa de que el desarrollo de significados e interpretaciones 
de recursos semióticos son dependientes de necesidades sociales y culturales (Achugar y Oteíza 2014; van Leeuwen 2014). Esto cobra mayor relevancia en el análisis de las imágenes seleccionadas, considerando el estado actual de la prensa nacional legitimada (ver sección 2.4).

\subsection{La relación entre texto e imagen: la contribución de un análisis asistido por corpus}

Una forma de complementar el análisis visual es el análisis del texto que rodea a las imágenes $y$, para ello, la utilización de metodologías de corpus puede facilitar el análisis cualitativo de los datos (Caple y Bednarek 2015). Uno de los objetivos de la aplicación de dichas metodologías en este tipo de estudios, es facilitar la identificación del efecto cumulativo de las palabras que contribuyen a la creación de discursos específicos (Baker 2006). Como el lenguaje es una práctica social, los significados evaluativos que le atribuimos a las palabras y a los recursos semióticos (que facilitan, entre otras cosas, la creación de estereotipos) dependen de contextos sociales particulares, reflejados en la repetición de patrones lingüísticos (Stubbs 2001). Se entiende, entonces, que el análisis de frecuencia de palabras (la cantidad de apariciones de una palabra en particular) y de colocaciones (la probabilidad de que una palabra en específico ocurra en conjunto con o cerca de otra) podría proporcionar una perspectiva complementaria con la cual contrastar qué tan asentadas se encuentran las prácticas discursivas representadas visualmente en los artículos noticiosos analizados.

Cabe destacar que el rol de las metodologías de análisis de corpus en este estudio solo es auxiliar en relación al análisis visual de las imágenes en cuestión. La función principal de esta metodología es comparar y/o contrastar las representaciones visuales y textuales de los manifestantes, contribuyendo al debate de la relación entre la fotografía periodística y el artículo noticioso en la cual se encuentra, yendo más allá del análisis del pie de foto. Esto se debe, entre otros aspectos, al reducido tamaño de mi corpus de estudio, insuficiente para realizar un análisis de corpus apropiado.

\subsection{La prensa escrita en Chile}

El golpe de Estado de septiembre de 1973 significó el cierre de diversas estaciones de radio y periódicos considerados peligrosos por la dictadura, dejando, por un lado, a unos pocos en la clandestinidad y resistiendo activamente al régimen militar ${ }^{1} \mathrm{y}$, por otro, un control casi absoluto de la Junta Militar sobre los medios de comunicación desde entonces oficiales, lo que se reflejó en los altos niveles de censura (impuesta o auto-impuesta) para mantener su circulación (Lugo-Ocando 2008). Una vez retornada la democracia, muchos de los canales de información clandestinos dejaron de existir, debido a la ausencia del rol regulador del gobierno sobre el financiamiento de los medios de comunicación, función que fue delegada al mercado. Esta medida implicó la desprotección de los diarios emergentes ante la imponencia de diarios como El Mercurio (perteneciente a la familia Edwards) y La Tercera (Copesa), los que consolidaron su posición al ser portavoces del gobierno militar, con quien tenían ideologías afines (Lugo-Ocando 2008).

Durante la dictadura, especialmente durante la década de 1980, se consolidan múltiples revistas comprometidas con la exposición de las violaciones a los derechos humanos perpetradas durante el régimen de la dictadura militar. Entre ellas, destacan las revistas Apsi, Hoy, Análisis, Cauce, La Bicicleta, incluso la existencia de un noticiario en VHS, Teleanálisis. 
Desde entonces, la prensa nacional es controlada por dos grupos económicos, El Mercurio S.A.P. y Copesa S.A., caracterizándose por ser un mercado oligopólico y un monopolio ideológico (Sunkel y Geoffroy 2001). Estos grupos, combinados, concentran más del $80 \%$ del índice de lectoría del país, siendo los más populares El Mercurio y Las Ultimas Noticias (Edwards), La Tercera y La Cuarta los que, en su conjunto, variaron entre $87 \%$ y $82 \%$ en niveles de lectoría durante el primer y segundo semestre de 2012, respectivamente (Marín 2014). En este contexto, muchos diarios emergentes, contrarios a la línea editorial de los grupos mencionados, han optado por el formato digital para costear gastos y mantener su circulación (Mönckeberg 2009).

Considerando que el rol de los medios comunicativos es decisivo en la legitimización de actores y eventos sociales, especialmente en relación a aquellos en posiciones de poder (Wodak 2008), vale la pena indagar en cómo se construyen los imaginarios sociales sobre el movimiento estudiantil en la prensa. Especialmente cuando existe evidencia de que la prensa establecida tiende a una criminalización lingüística sistemática de las acciones de los y las estudiantes en contextos de manifestaciones (Pérez 2012; Marín 2014), obviando las acciones que estos han utilizado como mecanismos representativos de participación social, que los llevaron a lograr que muchos temas públicos dejaran de ser tabú (Cabalin 2012; Cárdenas 2014a, 2014b).

\section{5. ¿Por qué el 4 de agosto de 2011?}

El movimiento estudiantil chileno, desde los inicios de la República, ha constituido un catalizador de cambios en la nación (Cabalin 2012), posicionándose como un actor social relevante en el quehacer político nacional (Bartoletti y Mangiantini 2010). Hasta el 2011, sin embargo, eran mayormente recordados por la "Revolución Pingüina" (2006), lo cual pareciera reflejar la tendencia a la invisibilización del rol de la juventud en Chile en la historia oficial (Cárdenas 2012), y del involucramiento político juvenil bajo la narrativa de "apatía juvenil" (Aguilera 2012: 103). Estas manifestaciones lideradas por los estudiantes secundarios (cuyo uniforme escolar se asemeja a los colores del pingüino) los posicionaron nuevamente en la agenda política y mediática, sorprendiendo con argumentos certeros y un manejo fluido de la jerga política en relación al estado del sistema educacional (Silva 2007). En un corto período de tiempo, su petitorio o lista de demandas cambia (exigen acceso gratuito al transporte público y a la Prueba de Selección Universitaria (PSU) para los tres quintiles más pobres, denuncian la mala implementación de la jornada escolar completa, entre otros) y se convierten en críticas sustanciales en contra del sistema educacional, enfocándose en la ilegitimidad e inefectividad de la Ley Orgánica Constitucional de Enseñanza (LOCE), promulgada el día anterior al término de la dictadura de Augusto Pinochet. Esta ley, cuyo énfasis estuvo en la regulación del sistema educacional bajo parámetros del mercado, debilitando el rol regulador del Estado, fue finalmente derogada tres años más tarde y reemplazada por la Ley General de Educación (LGE), que igualmente se basa en la misma premisa de una educación de mercado (Vera 2012).

En este contexto, las manifestaciones estudiantiles lideradas por universitarios $y$ secundarios el 2011 se enmarcan en una crisis de legitimidad del modelo educacional instaurado en la dictadura y perpetuado por los gobiernos de la Concertación que le siguieron (Fleet 2011). Si bien 
los y las estudiantes comenzaron a manifestarse en abril de ese año, es en agosto donde cuando la atención mediática se centra en sus acciones, debido a las marchas frustradas que intentaron realizar el 4 de agosto y los consiguientes "cacerolazos" ciudadanos en rechazo a la violencia desmedida de Carabineros (Vera 2012). Esto fue particularmente importante debido a las comparaciones explícitas con la dictadura militar, las cuales resonaron en la ciudadanía, especialmente al haber sucedido bajo el gobierno de Sebastián Piñera, representante de la coalición de la derecha política nacional. En palabras de Giorgio Jackson, ex dirigente estudiantil: "esos cacerolazos del 4 de Agosto fueron una respuesta ciudadana, que expresó de forma explícita su descontento. Fue espontáneo y surgió producto de errores muy graves del gobierno, que sitió la plaza Italia y recordó a la dictadura" (Zúñiga, Julio 2, 2012). Su importancia fue tal que, desde esas protestas, el 4 de agosto fue bautizado como el "día de los movimientos sociales y el despertar ciudadano" (Cárdenas 2014a). Finalmente, esa protesta significó el inicio de una radicalización tanto del movimiento social como del accionar del gobierno, reflejada en un mes fructífero en cuanto a demonstraciones ciudadanas a favor de reformas educacionales, que culminó con la muerte de un adolescente a manos de Carabineros en el contexto de un paro nacional convocado por la Central Unitaria de Trabajadores de Chile (CUT) en conjunto con la Confederación de Estudiantes de Chile (CONFECH).

\section{Corpus de estudio y metodología}

El corpus de estudio está compuesto por cuatro periódicos con cobertura nacional que cubrieron los acontecimientos del 4 de agosto de 2011, los cuales fueron diferenciados en dos categorías principales: prensa establecida y alternativa. Estas categorías reflejan su estatus social, siendo los primeros los que acaparan mayor financiamiento por parte de privados y del Estado, mientras que los otros han optado por el formato digital y/o de semanario debido a la falta de recursos monetarios (Herrera 2007). En la categoría de diarios 'establecidos' se encuentran El Mercurio y La Tercera, que corresponden a los ejemplares más vendidos del duopolio Edwards-Copesa a nivel nacional (Marin 2014). Por otro lado, los semanarios The Clinic y El Siglo representan a la prensa alternativa, debido a su particular línea editorial: mientras The Clinic es uno de los más populares debido a su tono satírico e irreverente ${ }^{2}$ (Bresnahan 2003), El Siglo corresponde a una publicación del Partido Comunista de Chile. Cabe destacar que si bien ambos semanarios están disponibles en formato impreso, solo The Clinic cuenta con un sitio web donde publica artículos noticiosos diariamente.

El corpus visual del estudio está compuesto por 42 imágenes, de las cuales 17 corresponden a diarios establecidos en su formato impreso: 7 de El Mercurio y 10 de La Tercera $\left.{ }^{3}\right)$ y 25 a diarios alternativos (5 de El Siglo ${ }^{4}$ y 20 de The Clinic ${ }^{5}$ ) extraídos online. Estas imágenes fueron codificadas con las iniciales de cada periódico y clasificadas numéricamente, siguiendo el orden en el que fueron introducidas en el artículo (de

El nombre The Clinic hace referencia al lugar donde Augusto $\mathrm{Pi}-$ nochet, líder de la dictadura chilena (1973-1990), fue retenido en Londres como prisionero en 1998.

3 https://www.dropbox.com/sh/iflku1d6y2a0tn4/AAAkC5rNwyB2heMaX7fQwlxRa?dl=0

4 https://www.dropbox.com/sh/yh3pts8xfw1azv7/AAAPESTor2lp_7qltOUGgW6qa?dl=0

5 https://www.dropbox.com/sh/odcdhzuitel7y0p/AACHe0pD9mVQwoklt3xOo7Pba?dl=0 
izquierda a derecha y desde el ángulo superior al inferior de la página). En este artículo, solo algunas imágenes son incluidas en el texto principal, mientras las demás pueden ser accedidas a través de los enlaces provistos. La excepción corresponde a las imágenes pertenecientes a El Mercurio, debido a que su reproducción (total o parcial) está prohibida. Estas, sin embargo, pueden ser revisadas a través del departamento de diarios y revistas de la Biblioteca Nacional de Chile.

La versión impresa de La Tercera fue descargada desde su sitio digital en formato PDF. En el caso de la prensa alternativa, se descargaron artículos referentes a la demonstración estudiantil desde el sitio digital de The Clinic. En cambio, se descargó el número completo en el caso de El Siglo, pero se utilizaron solo las imágenes y el texto que reportaban los eventos ocurridos el 4 de agosto de 2011. Las imágenes fueron analizadas siguiendo las categorías de la gramática visual (ver sección 2.2.).

Se realizó, además, un breve análisis de corpus para identificar las colocaciones y frecuencias más comunes, utilizando el software AntConc (Anthony 2014). El corpus total corresponde a 8.984 palabras, de las cuales 5.573 pertenecen a laprensa estableciday $3.411^{6}$ ala lalternativa. Este análisis textual es de carácter complementario al análisis visual y tiene por objetivo reflejar ampliamente las estrategias discursivas con las cuales se representa a los manifestantes en estos artículos, a través de la identificación de los procesos (acciones) más comunes con los cuales se representa a los manifestantes. Los resultados fueron normalizados por mil palabras

El artículo de El Siglo (2.442 palabras) incluye eventos anteriores a la protesta analizada, por lo cual solo se analizaron dos secciones pertinentes al evento estudiado (1.436 palabras). e interpretados utilizando el enfoque de Actores Sociales propuestos por van Leeuwen (2008).

\section{Análisis y resultados}

\subsection{La (in)visibilización de actores en la prensa escrita: ¿Qué y quiénes se ven?}

\section{El Mercurio}

Como se puede apreciar en la tabla 1, se identifica una clara tendencia a la criminalización de los manifestantes, al representar a Carabineros (incluyendo la ciudadanía, la propiedad pública y privada) como el objeto de sus violentas acciones (EM_2; EM_3; EM_5; EM_7) ${ }^{7}$. Si bien estas acciones tienden a ocupar un lugar central e importante en las imágenes, también hay algunas en las que los actores ocupan un lugar marginal, siendo sus acciones (violentas) centrales y posicionando al observador en el rol de testigo ocular. La inclusión de manifestantes vistiendo capuchas y accesorios que dificultan su identificación complementa esta representación negativa: por un lado, se muestran como grupos unificados al momento de "atacar" o "destruir"; por otro lado, también se les muestra como grupos desorganizados al momento de ser objetos del accionar de Carabineros (EM_1). Si bien EM_6 incluye una protesta pacífica, los manifestantes son enmarcados casi individualmente, lo que dificulta la representación del alcance de la protesta unísona de los cacerolazos de la noche del 4 de agosto. Asimismo, existe una inclusión mínima de los dirigentes estudiantiles, protagonizada

Como ya fue mencionado, estas y todas las imágenes tomadas de el diario El Mercurio pueden ser consultadas a través de pueden ser revisadas a través del departamento de diarios y revistas de la Biblioteca Nacional de Chile. 
por Camila Vallejo, quien es representada como la cara visible del movimiento en desmedro de la diversa composición del movimiento estudiantil, en un segundo plano de la imagen.
Los miembros de Carabineros son representados tanto con procesos de acción (mayoritariamente intransitivos) y como de reacción, excluyendo las acciones contra

Tabla 1. Análisis visual de los actores incluidos en El Mercurio

\begin{tabular}{|c|c|c|c|}
\hline & \multicolumn{3}{|c|}{ Significados } \\
\hline & Representacional & Composicional & Interactivo \\
\hline 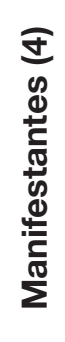 & $\begin{array}{l}\text { Procesos de acción: } \\
\text { - Atacan (carro lanza-aguas); } \\
\text { recolectan y destruyen } \\
\text { (señaléticas); escapan (de } \\
\text { gas lacrimógeno y avance de } \\
\text { Carabineros); golpean (ollas } \\
\text { y sartenes). }\end{array}$ & $\begin{array}{l}\text { Enmarcados como: a) una } \\
\text { unidad y marginados cuando } \\
\text { son actores de violencia; b) } \\
\text { desorganizados al ser objetos } \\
\text { de la acción de Carabineros. } \\
\text { Los resultados (violentos) y } \\
\text { objetos de sus acciones son } \\
\text { centrales. }\end{array}$ & $\begin{array}{l}\text { Distantes e inferiores al } \\
\text { observador, aunque también } \\
\text { construidos más cercanos y en } \\
\text { términos de igualdad cuando la } \\
\text { protesta es pacífica. }\end{array}$ \\
\hline 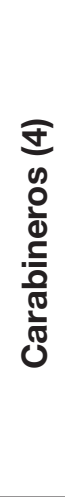 & $\begin{array}{l}\text { Procesos de acción: } \\
\text { - Apagan fuego (en el uniforme } \\
\text { de otro oficial); son atacados } \\
\text { (por manifestantes); ayuda (a } \\
\text { ciudadano a respirar). } \\
\text { Procesos de reacción: } \\
\text { - Observan (manifestantes } \\
\text { escapando de gas } \\
\text { lacrimógeno). }\end{array}$ & $\begin{array}{lr}\text { Representados como una } \\
\text { unidad, prominentes y } \\
\text { centrales en las imágenes. }\end{array}$ & $\begin{array}{l}\text { Construcción dual: a) } \\
\text { cercanos e involucrados con } \\
\text { el observador; b) se destaca } \\
\text { la posición de poder de estas } \\
\text { autoridades en relación a la } \\
\text { ciudadanía (ej. EM_7). }\end{array}$ \\
\hline 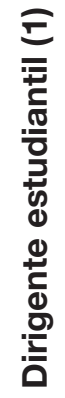 & $\begin{array}{l}\text { Proceso de reacción: } \\
\text { - Observan (a su izquierda } \\
\text { inferior). }\end{array}$ & $\begin{array}{l}\text { Camila Vallejo construida } \\
\text { dentro del marco de lo dado } \\
\text { y en segundo plano, mientras } \\
\text { que la otra persona (no } \\
\text { identificada) lo es como el foco } \\
\text { nuevo y saliente de la imagen. }\end{array}$ & $\begin{array}{l}\text { Se construyen como cercanos } \\
\text { al observador. Sin embargo, } \\
\text { prima la posición de poder del } \\
\text { observador y la indiferencia } \\
\text { de los dirigentes (hacia el } \\
\text { observador). }\end{array}$ \\
\hline
\end{tabular}


manifestantes. En EM_1, por ejemplo, los manifestantes escapan del gas lacrimógeno mientras los oficiales observan el caótico escape. Asimismo, la fuerza policial ocupa un lugar central, prominente y relativamente cercano al observador, especialmente cuando son el objeto de las acciones de manifestantes. Cabe destacar la construcción de Carabineros en el ámbito de lo ideal, donde se enfatiza su poder en la sociedad. La imagen EM_7 no solo presenta la única acción transitiva donde la agentividad de Carabineros es clara, sino que es positiva: el carabinero ayuda a un ciudadano (presumiblemente afectado por la protesta) a respirar con una mascarilla. En relación a la composición e interacción de la imagen, el oficial no solo se encuentra en una situación de poder ante el ciudadano, el cual pareciera estar arrodillado frente el, sino que también ante el observador, debido al ángulo inferior con el que se capturó la imagen.

También se identifica una tendencia a incluir imágenes que resalten la narrativa de conflicto y antagonismo entre la fuerza civil y los manifestantes. Se destaca la exclusión visual de la agentividad de la fuerza policial durante la protesta, al ser sus agentes presentados solo como pasivos o como objeto de las acciones de manifestantes. Finalmente, la exclusión del gobierno y de otros actores sociales involucrados en el movimiento es saliente (por ejemplo, Colegio de Profesores), lo cual pareciera complementar la narrativa escogida en la representación de los hechos.

\section{La Tercera}

Visualmente, este periódico incluye más actores sociales que en El Mercurio. Sin embargo, la narrativa principal de los reportes sigue siendo el conflicto y antagonismo entre manifestantes y la fuerza policial (tabla 2).

Las acciones violentas de los manifestantes lanzando una bomba lacrimógena (imagen 1) 0 atacando un carro policial (imagen 2)- son presentadas en imágenes donde aparecen rodeados de gas lacrimógeno, lo que intensifica la prominencia de estos actores en la imagen. Asimismo, tienden a estar representados cerca de losmárgenes delaimagen, quizás consolidando el

Imagen 1. LT_3

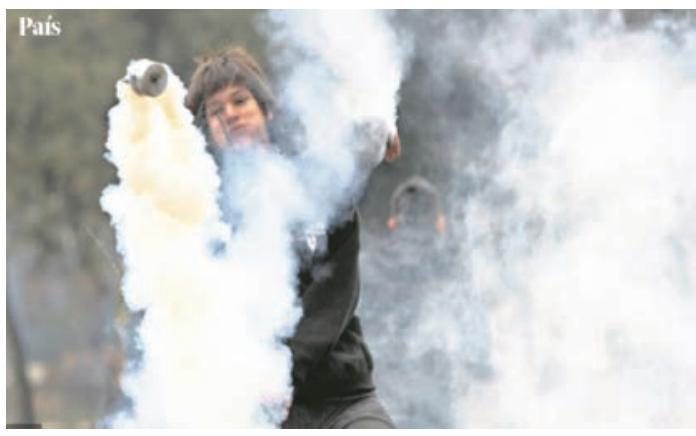

Fuente: J. Farias.

Imagen 2. LT_4

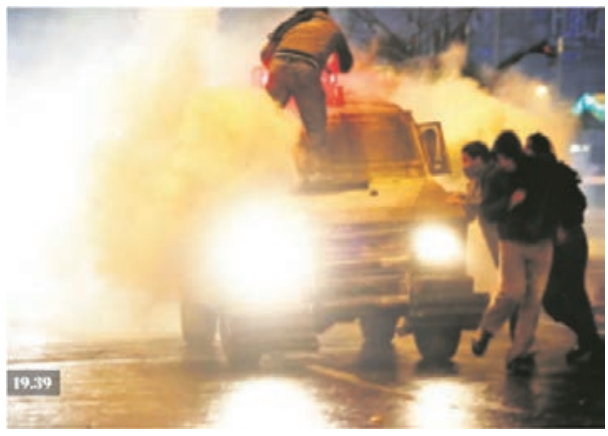

Fuente: Agencia Uno. 
Tabla 2. Análisis visual de los actores incluidos en La Tercera

\begin{tabular}{|c|c|c|c|}
\hline & & Significados & \\
\hline & Representacional & Composicional & Interactivo \\
\hline 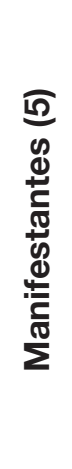 & $\begin{array}{l}\text { Procesos de acción: } \\
\text { - Golpean (ollas y sartenes); } \\
\text { lanza (bomba lacrimógena } \\
\text { hacia el observador); atacan } \\
\text { (carro lacrimógena); se } \\
\text { protegen (de carro lanza-agua). } \\
\text { Procesos de reacción: } \\
\text { - Observan (una barricada). }\end{array}$ & $\begin{array}{l}\text { Grupo cohesionadoal perpetrar } \\
\text { acciones violentas. Son } \\
\text { individualizados y prominentes } \\
\text { en la protesta pacífica. Los } \\
\text { resultados (violentos) y objetos } \\
\text { de sus acciones tienden a ser } \\
\text { centrales. Sus motivaciones } \\
\text { (reflejadas en un grafiti) se } \\
\text { encuentran en tercer plano, } \\
\text { siendo el mensaje obstruido } \\
\text { por otro manifestante. }\end{array}$ & $\begin{array}{l}\text { Distantes (e inferiores) } \\
\text { cuando son numerosos, y/o } \\
\text { grupos pequeños atacando a } \\
\text { Carabineros. Son más cercanos } \\
\text { y presentados en términos de } \\
\text { igualdad cuando la protesta es } \\
\text { pacífica o cuando la acción va } \\
\text { dirigida al observador (imagen 1). }\end{array}$ \\
\hline $\begin{array}{l}\text { लू } \\
0 \\
\frac{0}{0} \\
\frac{.}{0} \\
\frac{0}{\pi} \\
0\end{array}$ & $\begin{array}{l}\text { - Procesos de acción: } \\
\text { - Esatacado(pormanifestantes); } \\
\text { dispara gas lacrimógeno; } \\
\text { dispara agua (en dirección a } \\
\text { manifestantes). }\end{array}$ & $\begin{array}{l}\text { Son presentados en el plano } \\
\text { de lo nuevo cuando son } \\
\text { actores, y centrales cuando } \\
\text { estos son el objeto de } \\
\text { violencia de manifestantes. } \\
\text { Representaciones tienden a } \\
\text { ser cercanas }\end{array}$ & $\begin{array}{l}\text { A pesar de que no hay contacto } \\
\text { con el observador, se encuentran } \\
\text { relativamente cercanos y en } \\
\text { términos de igualdad con este. }\end{array}$ \\
\hline 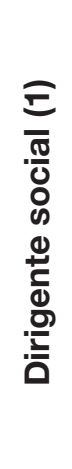 & $\begin{array}{l}\text { Proceso verbal: } \\
\text { - Habla (con los medios). }\end{array}$ & $\begin{array}{l}\text { Toma en blanco y negro. } \\
\text { Dirigente presentadodemanera } \\
\text { central y en primer plano, } \\
\text { destacan sus dientes. Segundo } \\
\text { plano sugiere la presencia de } \\
\text { dos actores más, quienes son } \\
\text { excluidos de la imagen al igual } \\
\text { que las motivaciones de este } \\
\text { movimiento social (impresos } \\
\text { pero obstruidos por estos dos } \\
\text { actores no identificados). }\end{array}$ & $\begin{array}{l}\text { Cercano y en un leve ángulo } \\
\text { superior que denota inferioridad } \\
\text { del observador en relación al } \\
\text { dirigente. No hay contacto con } \\
\text { el observador a pesar de ser una } \\
\text { toma frontal. }\end{array}$ \\
\hline $\begin{array}{l}\text { Ẽ } \\
\frac{0}{\frac{1}{0}} \\
\frac{0}{0} \\
\frac{0}{0}\end{array}$ & $\begin{array}{l}\text { Proceso de reacción: } \\
\text { - Observa (a su derecha). }\end{array}$ & $\begin{array}{l}\text { Toma en blanco y negro. } \\
\text { Actor mira hacia el sector } \\
\text { central-derecho de la imagen } \\
\text { (lo nuevo). Siluetas de otros } \\
\text { actores en segundo plano. }\end{array}$ & $\begin{array}{l}\text { Distancia íntima y términos de } \\
\text { igualdad con el observado. } \\
\text { No hay contacto entre actor y } \\
\text { observador. }\end{array}$ \\
\hline
\end{tabular}


estigma social del accionar de los encapuchados - manifestantes. Las distancias varían, pero existe una inclinación a crear una distancia con el observador, facilitando la colectivización y construcción de los manifestantes como un "otro" (out-group). Igualmente, el contacto con el observador es casi nulo, excepto por imagen 1, donde el manifestante pareciera arrojar una bomba lacrimógena hacia el observador. Al estar construido al mismo nivel que este, la acción pareciera involucrar al observador, sacándolo del rol de testigo ocular y posicionándolo en medio del conflicto.

Estas representaciones negativas de los manifestantes difieren con la única representación de manifestación pacífica (cacerolazos) incluida en el reporte. En ella, los manifestantes son más salientes y cercanos al observador, aunque el encuadre sugiere mayor individualidad en los manifestantes dirigiendo sus acciones a diversos puntos, dificultando su asociación con el colectivo social. Es importante mencionar que uno de los manifestantes en primer plano viste una capucha, sugiriendo una presencia omnipresente de la capucha tanto acciones positivas como negativas.

En relación a Carabineros, estos son construidos como agentes intransitivos, excluyendo el objeto de sus acciones (LT_58; LT_69). En el caso de LT_6, el chorro de agua del carro policial no va directamente dirigido a los manifestantes, ya que estos son excluidos del encuadre. Sin embargo, esta imagen fue recortada, y en otra versión con un encuadre mayor se distingue que el ataque va dirigido a personas $y / o$ manifestantes en

https://www.dropbox.com/sh/iflku1d6y2a0tn4/AAAkC5rNwyB2heMaX7fQwlxRa?dl=0\&preview=LT_5.png actitud pacífica (TC_2) ${ }^{10}$. En el caso de LT_5, el encuadre de la imagen permite inferir que si bien el oficial cumple con su deber de disuadir un posible disturbio (el cual es excluido de esta imagen), la acción no está dirigida a nadie en particular, lo que disminuye los riesgos de herir a manifestantes y/o civiles. Finalmente, hay un énfasis en la representación de Carabineros como el objeto de las acciones violentas de los manifestantes, posicionándose en un rol saliente y central en la imagen, mientras que los manifestantes son relegados al margen.

Es interesante observar la elección de textura (blanco y negro) para representar tanto al vocero del gobierno como al Presidente del Colegio de Profesores. La toma de Andrés Chadwick (LT_7 $)^{11}$ es desde un primer plano cercano, siendo excluido el fenómeno observado y delegando la responsabilidad de determinar cuál es el objeto de preocupación del actor representado al observador (Kress y van Leeuwen 2006). Esta representación contrasta con la imagen del dirigente social (LT_8) ${ }^{12}$, donde es representado como levemente superior al observador y se destacan sus dientes, evocando un aire de agresividad.

Cabe mencionar la inclusión de dos imágenes que representan el incendio en una multitienda (La Polar) durante la noche del día de protestas. Estas son imágenes aéreas donde el observador es confinado al rol de testigo ocular omnipresente de un evento que es, visualmente hablando, desagentilizado (deagentialised): no

10 https://www.dropbox.com/sh/odcdhzuitel7y0p/AACHe0pD9mVQwoklt3xOo7Pba?lst=\&preview=TC_2.jpg

11 https://www.dropbox.com/sh/iflku1d6y2a0tn4/AAAkC5rNwyB2heMaX7fQwlxRa?dl=0\&preview=LT_7.png

12 https://www.dropbox.com/sh/iflku1d6y2a0tn4/AAAkC5rNwyB2heMaX7fQwlxRa?dl=0\&preview=LT_8.png 
se incluye a quien(es) es(son) los responsables. Sin embargo, al ser incluido en los reportes sobre la protesta convocada por el movimiento estudiantil, el incendio se enmarca como consecuencia y efecto de esta.

\section{El Siglo}

El análisis visual refleja la ausencia de la narrativa de conflicto y antagonismo, ya que se acentúan las diversas asociaciones que componen el movimiento estudiantil, haciendo hincapié en la presencia de ACES y CoNES ${ }^{13}$ y en la manifestación pacífica, como se puede apreciar en la tabla 3:

Los dirigentes son representados en conversación con los medios de comunicación (inclusión de micrófonos con logos característicos de radios y canales de televisión nacionales), ocupando el lugar central de la imagen o el

Tabla 3. Análisis visual de los actores incluidos en El Siglo

\begin{tabular}{|c|c|c|c|}
\hline \multirow[b]{3}{*}{ 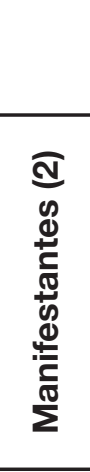 } & \multicolumn{3}{|c|}{ Significados } \\
\hline & Representacional & Composicional & Interactivo \\
\hline & $\begin{array}{l}\text { Procesos de acción: } \\
\text { - Marchan (por la calle). } \\
\text { Proceso verbal: } \\
\text { - Reclaman (al ser rodeados } \\
\text { por Carabineros). }\end{array}$ & $\begin{array}{l}\text { Son representados en tomas } \\
\text { en blanco y negro. Centrales } \\
\text { y prominentes en la imagen, } \\
\text { en actitud pacífica. Se destaca } \\
\text { una representación grupal y } \\
\text { unida. Se observan lienzos con } \\
\text { las motivaciones de la marcha } \\
\text { en segundo plano. }\end{array}$ & $\begin{array}{l}\text { En igualdad y relativamente } \\
\text { cercanos al observador, excepto } \\
\text { cuando son representados } \\
\text { reflejando la posición de } \\
\text { Carabineros, mostrándolos } \\
\text { como inferiores (imagen 4). }\end{array}$ \\
\hline 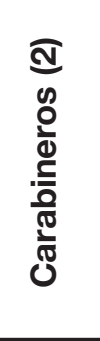 & $\begin{array}{l}\text { Procesos de acción: } \\
\text { - Camina (por la calle). } \\
\text { Procesos de reacción: } \\
\text { - Observan (rodeando a } \\
\text { manifestantes). }\end{array}$ & $\begin{array}{l}\text { Tomas en blanco y negro. } \\
\text { Marginales o presentados en } \\
\text { segundo plano, donde prima } \\
\text { la imagen del manifestante. } \\
\text { Presencia mínima y casi } \\
\text { individualizada. }\end{array}$ & $\begin{array}{l}\text { No hay contacto con el } \\
\text { observador (ya sea de espaldas, } \\
\text { u obstruidos por un dirigente } \\
\text { estudiantil). La distancia varía } \\
\text { de íntima a cercana, aunque } \\
\text { Carabineros se encuentran al } \\
\text { mismo nivel o medianamente } \\
\text { inferiores al observador. }\end{array}$ \\
\hline 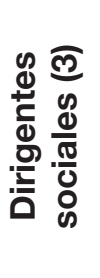 & $\begin{array}{l}\text { Proceso de reacción } \\
\text { - Observa (a su izquierda). } \\
\text { Proceso verbal } \\
\text { - Habla (con los medios, 2). }\end{array}$ & $\begin{array}{l}\text { Tomas en blanco y negro. } \\
\text { Centrales y salientes en las } \\
\text { imágenes (ocupan el primer } \\
\text { plano). }\end{array}$ & $\begin{array}{l}\text { No hay contacto con el } \\
\text { observador, aunque se presentan } \\
\text { de manera más cercana (la } \\
\text { distancia de las son casi íntimas) } \\
\text { y en términos de igualdad. }\end{array}$ \\
\hline
\end{tabular}

3 Asamblea Coordinadora de Estudiantes Secundarios y Coordinadora Nacional Estudiantes Secundarios, respectivamente. 
primer plano, cercanos al observador pero sin contacto directo. De forma similar, otro dirigente es representado en una reunión, observando pensativamente un fenómeno excluido de la imagen. Al igual que en LT_7, es el observador quien determina quién o qué puede ser el objeto de la mirada del dirigente, apelando tanto a presuposiciones como a representaciones evocadas por el texto escrito o el resto de las imágenes. Los dirigentes son representados como informados e informantes, al ser su mensaje compartido con los medios de comunicación y con distintos actores, como lo sugiere la reunión donde uno de ellos se encuentra.

Como se mencionó anteriormente, la narrativa del conflicto y antagonismo está ausente en este periódico semanal. Carabineros es representado como lejano al observador, siendo obstruido por otros actores o presentados de espaldas e imposibilitándose su identificación, excepto por el uso de sus uniformes. Su presencia es mínima, siendo construidos al margen de la imagen, donde el centro es ocupado por manifestantes congregados en actitud pacífica. Se destaca, además, la inclusión de las motivaciones e intenciones de los manifestantes en imagen 3, donde aparece un lienzo explicando que la marcha es por la educación y se muestra a jóvenes estudiantes, muchos vistiendo uniforme escolar. Esto, junto a la inclusión de ACES y CoNES, refuerza la presencia de estudiantes secundarios en la marcha, no solo reconociendo a diversos actores en el movimiento social, sino también facilitando la asociación de que la violencia desmedida registrada ese día fue ejercida contra menores de edad. Esto también se aprecia en imagen 4, donde los jóvenes manifestantes son rodeados por Carabineros y se aprecia que reclaman incrédulos (lenguaje
Imagen 3. ES_3

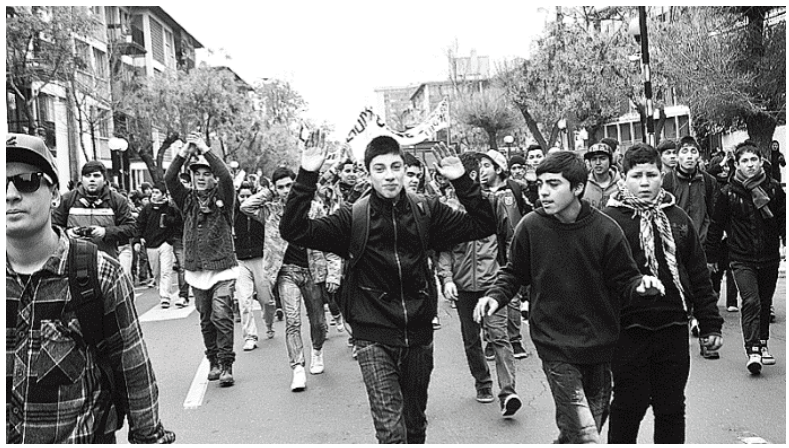

Fuente: autoría no incluida.

Imagen 4. ES_5

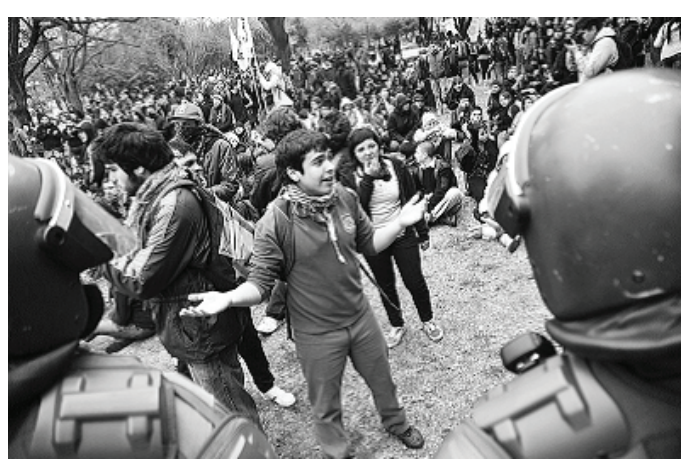

Fuente: autoría no incluida.

corporal), al estar congregados en lo que parece una plaza pública, en actitud pacífica (en el fondo de la imagen hay manifestantes sentados en el suelo, conversando entre sí).

El uso de la textura en blanco y negro puede ser interpretado de distintas maneras (menos costo al momento de la impresión, provocar ciertas reacciones del observador al representar dirigentes sociales que luchan contra un status quo, hacer los primeros planos más salientes, 
etc.). Sin embargo, cabe destacar las emociones evocadas con imagen 3 . El joven manifestante con las manos en alto -como símbolo de paz o de rendición- no solo pone de manifiesto las intenciones de los estudiantes, sino que también facilita asociaciones con la dictadura, al ser integrada en blanco y negro (Cárdenas, 2014b). Estas intenciones fueron explicitadas tanto por los dirigentes estudiantiles como por la ciudadanía, al recordar esta protesta.

\section{The Clinic}

La recopilación de imágenes de este periódico evoca, nuevamente, la narrativa del conflicto, lo cual puede ser evidenciado no solo por la inclusión exclusiva de manifestantes y Carabineros, sino también por el tipo de procesos con los cuales se les describe (tabla 4).

Esta narrativa, sin embargo, se inclina a construir a los manifestantes como el objeto de las acciones (a veces violentas e injustificadas) de Carabineros, las cuales se encontraban excluidas hasta ahora en el análisis. En estas imágenes, se ve a los manifestantes (muchos vistiendo uniforme escolar) superados en número; siendo "apresados" (imagen 6); "reducidos" violentamente (imagen 5); o a algunos efectivo de Carabineros ejerciendo su autoridad ante un manifestante hincado ante ellos (TC_10). Igualmente, se presenta a los manifestantes protegiéndose de las acciones de Carabineros, las que, de acuerdo al encuadre de la imagen, parecen ser injustificadas (TC_2; TC_12; TC_15) ${ }^{14}$. De estas imágenes, destaca

\footnotetext{
Ver los siguientes enlaces, respectivamente: https://www.dropbox.com/sh/odcdhzuitel7yOp/AAB-XAOxO7PkREhmsKm4lc-Wa/ TC_2.jpg?dl=0, https://www.dropbox.com/sh/odcdhzuitel7y0p/A ACZ7kZ54GS5m9MGY-yM9xFoa/TC_12.jpg?dl=0 y https://www. dropbox.com/sh/odcdhzuitel7y0p/AACHe0pD9mVQwoklt3xOo7Pba?lst=\&preview=TC_15.jpg
}

Imagen 5. TC_18

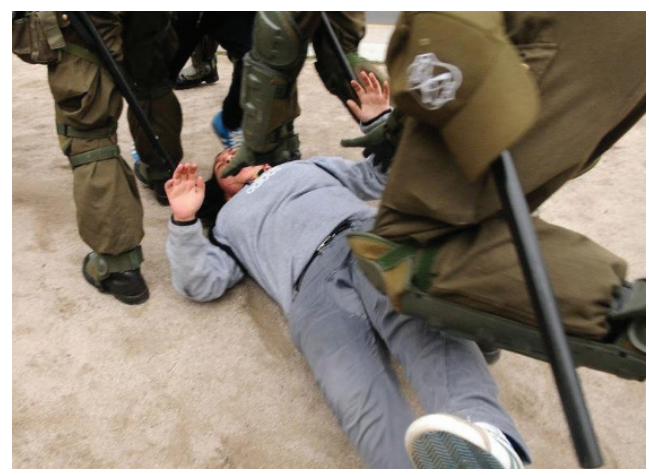

Fuente: autoría no incluida.

Imagen 6. TC_20

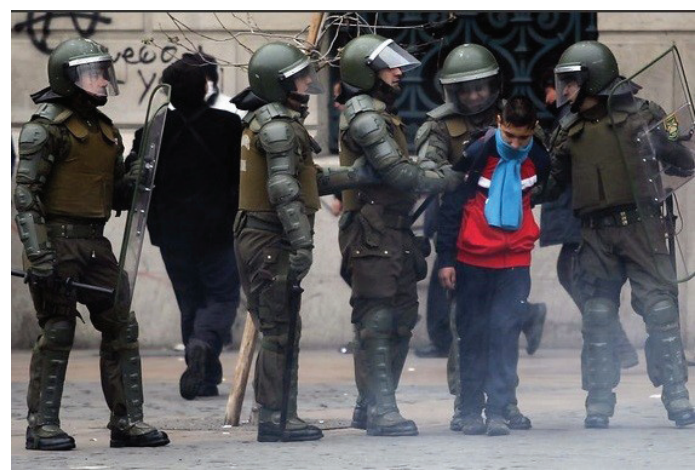

Fuente: autoría no incluida.

el caso de TC_2 y LT_6. Al tener un encuadre más amplio, el observador cuenta con un contexto mayor, donde se aprecia un (posible) manifestante en actitud pacífica y observando un fenómeno (excluido de la imagen), sin percatarse de la acción llevada a cabo por el carro lanza-agua. Al estar individualizado, la acción de Carabineros pierde legitimidad, implicando que la acción de disolver un eventual desorden público no correspondía, debido a la ausencia de este. En este nuevo encuadre, 
Tabla 4. Análisis visual de los actores incluidos en The Clinic

\begin{tabular}{|c|c|c|c|}
\hline & \multicolumn{3}{|c|}{ Significados } \\
\hline & Representacional & Composicional & Interactivo \\
\hline & $\begin{array}{l}\text { Procesos de acción: } \\
\text { - Sostiene (lienzo frente a Carabineros); } \\
\text { se protegen (de chorros de agua de } \\
\text { carros lanza-agua -(3)); golpea(n) } \\
\text { (ollas y/o sartenes -(4)); camina (en la } \\
\text { calle); esperan desafiantes (el avance } \\
\text { de Carabineros); agrega (materiales } \\
\text { a la barricada); es acarreado (por } \\
\text { Carabineros); está hincado (ante dos } \\
\text { oficiales); se congregan (en edificio, } \\
\text { presuntamente la Escuela de Derecho } \\
\text { de U. de Chile); es apresado (por } \\
\text { Carabineros (1) / agarrado por la cara } \\
\text { (1)); es reducido (por Carabineros). } \\
\text { Procesos de reacción: } \\
\text { - Observan (a manifestante hincado } \\
\text { (1), desde la azotea de un edificio (1)). }\end{array}$ & $\begin{array}{l}\text { La composición de las } \\
\text { imágenes es variada, aunque, } \\
\text { de manera general, se } \\
\text { concluye: a) los manifestantes } \\
\text { son centrales y/o salientes } \\
\text { cuando son objetos de las } \\
\text { acciones de Carabineros; } \\
\text { b) los manifestantes se } \\
\text { encuadran individualmente; c) } \\
\text { son difícilmente construidos en } \\
\text { relación a acciones violentas. }\end{array}$ & $\begin{array}{l}\text { Hay una clara tendencia a } \\
\text { construir a manifestantes } \\
\text { en términos de igualdad } \\
\text { con el observador (aunque } \\
\text { existen excepciones, de las } \\
\text { cuales cabe rescatar imagen } \\
7 \text {, donde manifestantes se } \\
\text { encuentran en un edificio } \\
\text { donde cuelga un lienzo con la } \\
\text { palabra "educación"). No hay } \\
\text { contacto con el observador, } \\
\text { excepto en la imagen TC_10', } \\
\text { donde se mira en un ángulo } \\
\text { superior al observador. } \\
\text { Las distancias varían entre } \\
\text { íntimas a lejanas, donde las } \\
\text { últimas tienden a reflejar la } \\
\text { dinámica antagónica entre } \\
\text { ellos y Carabineros. }\end{array}$ \\
\hline & $\begin{array}{l}\text { Procesos de acción: } \\
\text { - Dispara (chorro de agua en dirección } \\
\text { a manifestantes (1) / bomba } \\
\text { lacrimógena (1)); avanzan (por la } \\
\text { calle); patea (barricada); avanzan } \\
\text { (hacia manifestantes -(3)); forcejean } \\
\text { (con estudiante); apunta (en dirección } \\
\text { a manifestante en el suelo); caminan } \\
\text { (por paso peatonal); apunta (hacia } \\
\text { dos direcciones distintas); reduce (a } \\
\text { manifestante caído -1) agarrándole la } \\
\text { cara (-1); apresan (a joven)". } \\
\text { Procesos de reacción: } \\
\text { - Observa(n) (a manifestante(s))" }\end{array}$ & $\begin{array}{l}\text { Se destaca en la construcción } \\
\text { composicional de Carabineros: } \\
\text { a) el encuadre enfatiza uniforme } \\
\text { y la acción grupal; b) difícil } \\
\text { identificación (presentados de } \\
\text { espaldasalacámara); c)tienden } \\
\text { a ser construidos marginales } \\
\text { o cercando el centro de la } \\
\text { imagen, especialmente cuando } \\
\text { este representa a estudiantes; } \\
\text { d) posicionados en el ámbito de } \\
\text { lo nuevo y dado; e) sobresalen } \\
\text { (por el uniforme) y se presentan } \\
\text { como grupos pequeños e } \\
\text { individualizados. }\end{array}$ & $\begin{array}{l}\text { Si bien hay tendencia a } \\
\text { presentarlos al mismo } \\
\text { nivel que el observador } \\
\text { (7 imágenes), también se } \\
\text { construyen como superiores } \\
\text { a este (1 imagen). Asimismo, } \\
\text { aunque técnicamente } \\
\text { hay imágenes donde el } \\
\text { observador se encuentra en } \\
\text { poder (3), el ángulo sugiere el } \\
\text { punto de vista de los efectivos } \\
\text { debido a la distancia cercana } \\
\text { entre ellos y el observador. } \\
\text { El contacto entre observador } \\
\text { y actores es limitado, siendo } \\
\text { la excepción TC_12, ya } \\
\text { que un oficial apunta al } \\
\text { observador. }\end{array}$ \\
\hline
\end{tabular}


además, se incluye la forma visible de un camarógrafo vistiendo un traje y una mascarilla que pareciera protegerle tanto del agua como del gas lacrimógeno, y enfocando el objetivo final del carro lanza-agua. Aun así, es imposible determinar la pertenencia de este camarógrafo, ya que podría corresponder a un medio de comunicación nacional o a la policía.

Así como se incluyen acciones transitivas de Carabineros, también se incluyen imágenes donde el manifestante se asocia con encapuchados en actitud desafiante, aunque en menor cantidad (TC_4; TC_8) ${ }^{15}$. En TC_4, por ejemplo, se distingue la silueta de un manifestante encapuchado en primer plano, caminando en un fondo donde una estructura se está incendiando. Camina hacia el lado derecho de la imagen, donde de fondo se distingue un cartel "SEGURIDAD SANTIAGO" invertido. EI juego de luces provocado por el fuego facilita una construcción dramática de la violencia y destrozos durante las protestas, donde los valores manifestados y reforzados por el gobierno (seguridad) son literalmente invertidos y sobrepasados por la desobediencia civil.

En la representación de los manifestantes también destaca una mayor inclusión de la protesta de cacerolazos $^{16}$. En estas imágenes destaca la inclusión de una persona mayor golpeando un sartén con un palo y de una joven realizando la misma acción, ambas cercanas al

15 https://www.dropbox.com/sh/odcdhzuitel7y0p/AACHe0pD9mVQwoklt3xOo7Pba?lst=\&preview=TC_4.jpg y https://www.dropbox.com/sh/odcdhzuitel7y0p/AACHe0pD9mVQwoklt3xOo7Pba?lst=\&preview=TC 8.jpg

16 Es más, TC 3 (https://www.dropbox.com/sh/odcdhzuitel7y0p/ AACHe0pD9mVQwoklt3xOo7Pba?lst=\&preview=TC_3.jpg) se repite en el artículo, siendo también incluida en La Tercera (https:// www.dropbox.com/sh/iflku1d6y2a0tn4/AAAkC5rNwyB2heMaX$7 f Q w \mid x R a$ ?dl=0\&preview=LT_2.png). observador y mirando al horizonte (fenómenos excluidos) y en actitud seria, lo cual sugiere el rol activo del observador en el descifrar cuál puede ser el objeto de sus miradas. Debido a la inclusión del accionar, a veces violento, de Carabineros, y las asociaciones directas a la dictadura al describir el actuar policial, la actitud seria podría sugerir y facilitar la interpretación de esta como una crítica transgeneracional a los eventos del día.

Finalmente, cabe destacar la inclusión de las motivaciones detrás de la convocatoria a las protestas, a través de la representación de lienzos con las demandas del movimiento estudiantil. Mientras que TC_1 $1^{17}$ se puede interpretar como las demandas estudiantiles y los representantes del poder institucionalizado literalmente divididos y asimétricos en su relación (lienzo y Carabineros se encuentran separados por una torre en el fondo, dividiendo la imagen en dos), imagen 7 posiciona las

Imagen 7. TC_13

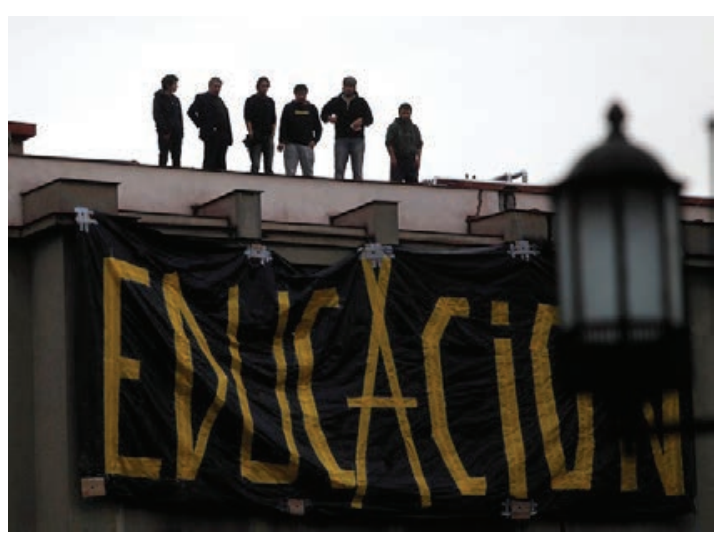

Fuente: autoría no incluida

https://www.dropbox.com/sh/odcdhzuitel7y0p/AACHe0pD9m- 
demandas estudiantiles como centrales en la imagen y a los manifestantes en el área de lo ideal y empoderados, legitimando su rol como agentes de cambios como la de sus demandas.

\subsection{La correlación entre imágenes y texto}

Al contrastar los resultados del análisis multimodal con el análisis textual, podemos identificar la repetición del mismo patrón visual al representar las acciones de los manifestantes, señalados en la siguiente tabla.
En relación a las estrategias referenciales, los resultados revelan la falta de diferenciación en la prensa establecida de los distintos agentes involucrados en la protesta. En primer lugar, hay una importante presencia del constructo "estudiante(s)" en esta prensa, el cual no solo enfatiza la funcionalidad de estos actores, sino que también la responsabilidad de movimientos estudiantiles en la convocatoria a la marcha. Este resultado sugiere que el imaginario del estudiante es el principal actor asociado a las marchas, del cual se desprenden los demás sinónimos

Tabla 5. Frecuencia normalizada de la representación de manifestantes en la prensa establecida (PE) y alternativa (PA) y los procesos (acciones) asociados a éstos al ser agentes (+OL/+1R).

\begin{tabular}{|c|c|c|}
\hline & Prensa establecida & Prensa alternativa \\
\hline $\begin{array}{c}\text { Estudiante } \\
\text { (PE: } 5.02 \text { / PA: 5.28) }\end{array}$ & $\begin{array}{l}\text { Preparar (rechazo), confirmar (marcha), } \\
\text { poder (acceder a material escolar). }\end{array}$ & $\begin{array}{c}\text { resolver; } \\
\text { desafiar (un gobierno sordo). }\end{array}$ \\
\hline $\begin{array}{c}\text { Manifestante } \\
\text { (PE: } 2.33 \text { / PA: 1.17) }\end{array}$ & $\begin{array}{l}\text { transitar, colocar-instalar (barricadas), } \\
\text { intentar (marchar-cortar el tránsito). }\end{array}$ & pasar (transitar). \\
\hline $\begin{array}{l}\text { Universitario } \\
\text { (PE: } 0 \text { / PA: 0.88) }\end{array}$ & - & $\begin{array}{l}\text { aprovechar (la pausa); } \\
\text { presentar (propuesta). }\end{array}$ \\
\hline $\begin{array}{c}\text { Secundario } \\
\text { (PE: } 0 \text { / PA: 0.88) }\end{array}$ & - & $\begin{array}{l}\text { presentar (propuesta); } \\
\text { Ilegan (a la convocatoria). }\end{array}$ \\
\hline $\begin{array}{l}\text { Encapuchado } \\
\text { (PE: } 0.72 \text { / PA: 0) }\end{array}$ & $\begin{array}{l}\text { lanzar (bombas incendiarias); } \\
\text { colocar (barricadas). }\end{array}$ & - \\
\hline $\begin{array}{c}\text { Violentista } \\
\text { (PE: } 0.18 \text { / PA: 0) }\end{array}$ & forzar (cortinas metálicas). & - \\
\hline $\begin{array}{c}\text { Turba } \\
\text { (PE: } 0.18 \text { / PA: 0) }\end{array}$ & atacar (a voluntarios de Bomberos). & - \\
\hline $\begin{array}{c}\text { Vándalo } \\
\text { (PE: } 0.18 \text { / PA: 0) }\end{array}$ & $\begin{array}{c}\text { destrozar (bancos, casetas de seguridad); } \\
\text { levantar (barricadas). }\end{array}$ & - \\
\hline $\begin{array}{c}\text { Joven } \\
\text { (PE: } 2.51 / \mathrm{PA}: 0)\end{array}$ & $\begin{array}{l}\text { luchar (por algo justo); } \\
\text { lanzar (artefactos incendiarios). }\end{array}$ & - \\
\hline
\end{tabular}


reflejados en la tabla. En segundo lugar, hay una clara inclinación a la colectivización de la actividad que realizan -estudiar- y del grupo etario al cual pertenecen ("jóvenes"), más que del tipo de estudiante involucrado (universitario o secundario). Esto no solo pareciera reflejar una invisibilización de distintos colectivos que conforman este movimiento social, sino que también el repertorio de demandas que diferencian a los estudiantes secundarios de los universitarios. Finalmente, se aprecia una selección de procesos materiales negativos ("destrozar", "forzar", "luchar", o "atacar") que destacan las acciones violentas de las jornadas. Incluso aquellos procesos que no connotan acciones negativas per se, tales como "levantar" o "lanzar", son predicados con acciones y/u objetos asociadas a protestas y desorden civil. Al igual que en las imágenes analizadas, hay un énfasis en la narrativa del conflicto y antagonismo, representando al movimiento y a los manifestantes en oposición a Carabineros y al gobierno.

Esta representación negativa de los estudiantes cambia al momento de analizar la prensa alternativa, en donde destacan procesos materiales y mentales que construyen a los estudiantes como actores racionales. Si bien la funcionalidad de los manifestantes también es recurrente, en estos textos sí se incluye una terminología que identifica la diversidad dentro del movimiento estudiantil (por ejemplo, "universitarios" y "secundarios") en términos positivos, contrario a la prensa establecida, donde se tiende a la colectivización (negativa). Esta construcción, excluida en la prensa establecida, pareciera legitimar el rol de los jóvenes como agentes activos y pensantes, capaces de hacer y pensar, sobre todo a través de la exclusión de términos inherentemente negativos (tales como "encapuchados"). Sin embargo, existe una pequeña diferencia entre las acciones representadas textualmente y las imágenes incluidas, ya que en las imágenes se tiende a destacar el rol de los estudiantes como objetos de la violencia policial, característica ausente en el análisis textual.

\section{Comentarios finales}

A través de este artículo se intentó determinar cómo los distintos actores involucrados en las protestas estudiantiles convocadas el 4 de agosto de 2011 fueron visualmente representados, tanto en los reportes de la prensa establecida como en aquellos de la prensa alternativa, abogando por un enfoque multimodal. Los resultados del análisis visual en la prensa establecida revelaron una clara inclinación por una narrativa de conflicto y antagonismo entre manifestantes y Carabineros. Si bien esto se asemeja a resultados sobre cómo se reporta la protesta social, los resultados ponen de manifiesto cómo las imágenes y el texto trabajan conjuntamente para representar y legitimar la realidad y las acciones del status quo en la prensa establecida. Las imágenes tienden a representar a la fuerza policial indefensa y sobrepasada por las acciones de los manifestantes, donde estos últimos son representados mayormente como agentes de violencia y destrucción. Además, hay una inclinación a la colectivización de los manifestantes y actores sociales involucrados en el movimiento, lo cual facilita la asociación de estudiantes, manifestantes y encapuchados, tal y como lo revela el análisis de corpus. Asimismo, los oficiales se tienden a construir como realizando acciones intransitiva y excluyendo de la imagen el objeto de sus acciones es y, de esa forma, deslegitimando las acusaciones de violencia desmedida contra manifestantes. 
Aunque los resultados del análisis visual en la prensa alternativa también revelaron la inclusión de la narrativa de conflicto y antagonismo (por lo menos en The Clinic), esta sí incluye a Carabineros como agentes transitivos, cuyos objetos eran manifestantes o menores de edad. Hay una tendencia a incluir a manifestantes como agentes organizados (El Siglo) y como objeto de las acciones de Carabineros (The Clinic), construcciones que son excluidas en la prensa establecida. Igualmente, hay una inclusión de las motivaciones y demandas del movimiento social, también excluidas en El Mercurio o La Tercera. Se destaca también que en EI Siglo la diferenciación de los distintos actores involucrados hace hincapié en la participación de agrupaciones de estudiantes secundarios. La inclusión que realiza El Siglo es destacable, puesto que las agrupaciones estudiantiles secundarias son totalmente excluidas en la prensa establecida, ya que estos medios se centran mayormente en el rol de los universitarios.

La representación visual de estas acciones fue corroborada por un breve y acotado análisis de las estrategias referenciales y colocaciones verbalesusadas en estos artículos paraidentificar a los estudiantes. Algunos de los términos identificados ("encapuchado", "vándalo", etc.) intensifican la narrativa de conflicto y antagonismo con Carabineros, especialmente al ser asociados a acciones negativas en la prensa establecida (como "lanzar/colocar barricadas", "atacar a voluntarios de Bomberos", etc.). Cabe destacar que este artículo solo examinó un corpus limitado de imágenes y texto, por lo que la inclusión de más imágenes y/o periódicos podría dar más detalles sobre la construcción de un discurso criminalizador sobre los manifestantes y los contra-discursos que los identifican como actores de cambios legítimos, con demandas socialmente apoyadas.

El acceso a fuentes de información es una de las diversas maneras de ejercer poder en una sociedad, donde se tiende a servir propósitos $\mathrm{y} / \mathrm{o}$ intereses de un grupo particular en desmedro de otro (van Dijk 2006). Si bien los resultados de este análisis son exploratorios, estos dejan entrever cómo la prensa establecida construye narrativas que facilitan la legitimación de las acciones del gobierno y de la fuerza policial -lo institucionalizado; lo correcto-y deslegitiman las acciones y demandas del movimiento social -lo malo; ilegal; irracional-, estrategias comunes de la legitimación (van Leeuwen 2007). Asimismo, se transmite una realidad conforme a los intereses de un grupo en particular, por lo que las demandas sobre una reforma educacional junto con los actores que las promueven- son representadas en base a la criminalización y colectivización o, en su defecto, excluidas. 


\section{Bibliografía}

Achugar, M. y Oteíza, T. 2014. "Recontextualización del pasado reciente: prácticas sociales multisemióticas". Discurso y Sociedad, 8 (1): 1-11.

Aguilera, O. 2012. "Repertorios y ciclos de movilización juvenil en Chile (2000-2012)". Revista Internacional de Filosofía Iberoamericana y Teoría Social , 57: 101-108.

Anthony, L. 2014. AntConc (Version 3.4.3) (Computer Software). Tokyo, Japan: Waseda University. Disponible en http:// www.laurenceanthony.net/

Baker, P. 2006. Using corpora in discourse analysis. Londres: Continuum.

Baker, P. Gabrielatos, C., Khosravinik, M., Krzyżanowski, M., McEnery, T. y Wodak, R. 2011. “¿Una sinergia metodológica útil? Combinar análisis crítico del discurso y lingüística de corpus para examinar los discursos de los refugiados y solicitantes de asilo en la prensa británica". Discurso y Sociedad, 4 (4): 376-416.

Barthes, R. 1977. Image, Music, Text. Londres: Fontana.

Bartoletti, J. y Mangiantini, M. 2010. "El movimiento estudiantil chileno reciente. Algunos elementos para su análisis". Presentación en III Jornadas de estudio y reflexión sobre el movimiento estudiantil Argentino y Latinoamericano, La Plata (Argentina).

Bresnahan, R. 2003. "The Media and the Neoliberal Transition in Chile: Democratic Promise Unfulfilled". Latin American Perspectives, 30 (6): 39-68.

Cabalin, C. 2012. "Neoliberal education and student movements in Chile: inequalities and malaise". Policy Futures in Education, 10 (2): 219-228.

Caple, H. 2013. Photojournalism: A Social Semiotic Approach. Basingstoke: Palgrave Macmillan.

Caple, H. y Bednarek, M. 2015. "Rethinking news values: What a discursive approach can tell us about the construction of news discourse and news photography". Journalism, 1-22.

Cárdenas, C. 2014a. "Inútiles y subversivos: representación transmedia de los estudiantes chilenos en redes sociales". Romanica Olomucensia, 26 (2): 173-190.

2014b. "Representación visual de la movilización estudiantil en Chile: las fotografías de las marchas como espacios de narración, actuación e identificación política". Onomázein, Número especial IX ASFAL: 115-137.

. 2012. “¿Dónde debe emplazar su ojo la historia? (In)visibilización de las y los jóvenes en discursos disciplinares que recuperan el pasado reciente chileno (1970-1990)". Discurso y Sociedad, 6 (2): 283-313.

Chan, J. y Lee, C. 1984. "The journalistic paradigm on civil protests: A case study of Hong Kong". The news media in national and international conflict. Arno, A. y Dissanayake, W. (Eds.). Boulder: Westview Press.

Colorado, C. 2011. "Categorización y Agentividad de la Protesta Social en la Prensa Española". Presentación en XXVI
Encuentro Internacional de la Asociación de Jóvenes Lingüistas. Salamanca, España. Press.

Dondis, D. 1973. A primer of visual literacy. Londres: The MIT

El Mercurio. 2011, 05 Agosto. "Jornada de protestas estudiantiles afecta a 12 ciudades y deja 552 detenidos en el país". Departamento de Diarios y Revistas. Biblioteca Nacional de Santiago. Chile.

El Siglo. 2011, 05 Agosto. "A respuestas insuficientes, movilizaciones permanentes". Descargado de http://issuu.com/ semanarioelsiglo/docs/semanario_el_siglo_n1570/1

Fleet, N. 2011. "Movimiento estudiantil y transformaciones sociales en Chile: una perspectiva sociológica". Revista de la Universidad Bolivariana, 10 (30): 99-116.

Halliday, M. 2004. An introduction to functional grammar (Christian M. I. M. Matthiessen Ed. 3rd ed.). Londres: Arnold.

Herrera, M. 2007. "Democracia tutelada y libertad de expresión en Chile". Presentación en Tramas de la comunicación en América Latina contemporánea. Tensiones sociales, políticas y económicas, Uncuyo, Mendoza.

Kress, G. 2010. Multimodality: a social semiotic approach to contemporary communication. Londres: Routledge.

Kress, G. y van Leeuwen, T. 2006. Reading images: the grammar of visual design (2nd ed.). Londres: Routledge.

La Tercera. 2011, 05 Agosto. "Desmanes y cacerolazos marcan jornada de protestas". PDF descargado de "versiones anteriores" de www.latercera.com

Lugo-Ocando, J. 2008. The Media in Latin America. Maidenhead: Open University Press.

Machin, D. 2007. Introduction to multimodal analysis. Londres: Hodder Arnold.

Machin, D. 2013. "What is multimodal critical discourse studies?". Critical Discourse Studies. 10 (4): 347-355.

Marín, F. 2014. Las batallas por la Alameda: arteria del Chile demoliberal. Santiago: Ceibo.

Mautner, G. 2008. "Analyzing newspapers, magazines and other print media". Qualitative discourse analysis in the social sciences. Wodak, R. y Krzyzanowski, M. (Eds.). Hampshire: Palgrave McMillan. 30-53.

McLeod, D. 2007. "News coverage and social protest: How the media's protest paradigm exacerbates social conflict". Journal of Dispute Resolution. 1: 185-194.

Mönckeberg, M. 2009. Los magnates de la prensa. Santiago: Debate.

O'Halloran, K. 2011. "Multimodal Discourse Analysis". Continuum Companion to Discourse Analysis. Hyland, K. Y Paltridge, B. (Eds.). Londres: Continuum. 120-137.

Pérez, C. 2012. "The Chilean Student Movement And The Media: A Comparative Analysis On The Linguistic Representation Of The 04 August, 2011 Manifestation In Right-Wing And Left- 
Wing Newspapers". Logos: Revista de Lingüística, Filosofía y Literatura. 22 (2): 4-26.

Shoemaker, P. 1984. "Media treatment of deviant groups". Journalism Quarterly, 6 (1): 66-82.

Silva, B. 2007. "La Revolución Pingüina y el cambio cultural en Chile". Centro de Estudios sobre Cultura, Politica, y Sociedad. Descargado de http://bibliotecavirtual.clacso.org.ar/ar/ libros/becas/2007/cultura/silva.pdf

Stubbs, M. 2001. Words and Phrases. Oxford: Blackwell Publishing

Sunkel, G. 2001. La Concentración económica de los medios de comunicación en Chile. Santiago: Editorial LOM.

The Clinic. 2011, 04 Agosto. "Las mejores fotos de la movilización estudiantil". Descargado de http://www.theclinic. cl/2011/08/04/las-mejores-fotos-de-la-no-marcha/

The Clinic. 2011, 05 Agosto. "Hinzpeter transforma marchas estudiantiles en protesta nacional". Descargado de http://www. theclinic.cl/2011/08/05/el-4a-chileno-jornada-represiva-terminocon-cacerolazos/

Torres, E. 2006. "El tratamiento de la imagen en los atentados del 11-M. terrorismo y violencia en la prensa. Revista Latina de Comunicación Social, 61. En línea, disponible en: http://www.ull. es/publicaciones/latina/200603torres.htm (visitado 01 de octubre de 2015)
Van Dijk, T. 2006. "Discourse and Manipulation". Discourse \& Society, 17 (3): 359-383.

Van Leeuwen, T. 2014. "Critical Discourse Analysis and Multimodality". Contemporary Critical Discourse Analysis. Christopher H. y Cap, P. (Eds.). Londres: Bloomsbury. 281-295.

Van Leeuwen, T. 2008. Discourse and practice: New tools for critical discourse analysis. Oxford: Oxford University Press.

Van Leeuwen, T. 2007. "Legitimation in discourse and communication". Discourse \& Communication, 1 (1): 91-112.

Van Leeuwen, T. y Jewitt, C. 2001. Handbook of visual analysis. Londres: Sage.

Vera, Sandra. 2012. "Cronología del conflicto: el movimiento estudiantil en Chile, 2011". Anuario del Conflicto Social. Barcelona.

Wodak, R. 2008. "'Us' and 'them': Inclusion and exclusion -Discrimination via discourse". Identity, belonging and migration. Delanty, G. y Wodak, R. (Eds.). Liverpool: Liverpool University Press.

Zelizer, B. 2004. "When war is reduced to a photograph". Reporting war: Journalism in wartime. Stuart A. y Zelizer, B. Londres/Nueva York: Routledge. 115-135.

Zúñiga, D. Julio, 02. 2012. "Giorgio: "He sido un privilegiado, pero tengo deuda en la universidad"”. Las Ultimas Noticias, p. 14. Descargado de http://www.lun.com/Pages/NewsDetail. aspx?dt=2012-07-02\&Paginald $=14 \&$ bodyid $=0$ 